U. S. DEPARTMENT OF COMMERCE HARRY L. HOPKINS, Secretary

NATIONAL BUREAU OF STANDARDS

LYMAN J. BRIGGS, Director

Burear of ftandardis MAY 251940

\title{
SANITARY CAST-IRON ENAMELED WARE
}

\section{COMMERCIAL STANDARD CS77-40}

[Supersedes CS77-39, Mimeographed]

Effective Date for New Production May, 25, 1940

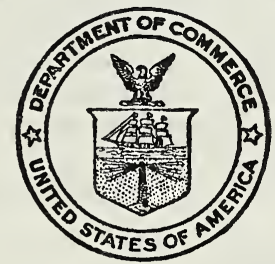

A RECORDED VOLUNTARY STANDARD OF THE TRADE

UNITED STATES

GOVERNMENT PRINTING OFFICE

WASHINGTON : 1940 


\section{PROMULGATION}

of

\section{COMMERCIAL STANDARD CS77-40}

for

\section{SANITARY CAST-IRON ENAMELED WARE}

On April 12, 1939, at the instance of the Sanitary Cast Iron Enameled Ware Association, a proposed commercial standard was submitted to the interested national associations for comment. Following adjustment to suit the composite recommendations of all concerned, it was accepted in writing by manufacturers, distributors, master plumbers, and users, and promulgated as Commercial Standard CS77-39.

On March 30, 1940, a recommended revision submitted by the Sanitary Cast Iron Enameled Ware Association and endorsed by the standing committee was circulated to the trade with notice that in view of the minor character of the revision it would be promulgated in the absence of objections. Accordingly, in the absence of such objections and with the support of many additional acceptances, the revised standard as shown herein is approved by the trade for promulgation by the United States Department of Commerce, through the National Bureau of Standards.

The standard is effective for new production from May 25, 1940.

Promulgation recommended.

Promulgated.

I. J. Fairchild, Chief, Division of Trade Standards.

Lyman J. Briggs,

Promulgation approved. Director, National Bureau of Standards.

Harry L. Hopkins, Secretary of Commerce. 


\section{SANITARY CAST-IRON ENAMELED WARE}

\section{COMMERCIAL STANDARD CS77-40}

\section{PURPOSE}

1. The purpose is to establish minimum standard specifications, definitions, inspection rules, and methods of test for sanitary castiron enameled ware for the guidance of manufacturers, distributors, and users of this product. By its general acceptance and use, and by means of labels certifying conformity with this standard, it is hoped to improve both the quality and acceptance of this ware to the mutual advantage of all concerned.

\section{SCOPE}

2. This standard provides minimum requirements for sanitary cast-iron enameled ware, such as bathtubs, lavatories, kitchen sinks, laundry trays, drinking fountains, and similar fixtures. Requirements include material, thickness, warpage, enameling, acid-resistance, inspection rules, and marking.

\section{GENERAL REQUIREMENTS}

3. Material of base.-The metal base shall be one-piece, high-grade cast iron, strong, sound, true to form, free from porosity or any other defects which may affect the serviceability of the fixtures.

4. Thickness of base metal.-The cast-iron base shall have a thickness of not less than $1 / 8$ inch at any point not less than 1 inch from any edge.

5a. Enameling.-The enameled surface of each fixture shall be coated with porcelain enamel applied by the dry process, thoroughly fused to the cast-iron base. There shall be no appearance of inadequate covering. The enamel shall be glossy and free from flaws which affect the appearance or may affect the serviceability of the fixture. The thickness of the enamel ${ }^{1}$ as measured on a flat surface at least 1 inch from any edge shall be not less than 0.025 inch. Blemishes shall be limited in accordance with the inspection rules herein. The unenameled surface of each fixture shall be treated with one coat of filler, ground coat, or paint.

5b. Acid-resisting enamel shall be acid resisting throughout the entire enamel thickness and shall pass successfully the tests specified in paragraph 12.

6. Warpage.-Warpage of edges set against wall or floor shall not exceed 1116 inch per foot when tested according to the method outlined in paragraph 11. Warpage of all other edges shall not exceed $3 / 32$ inch per foot when tested according to the same method.

\footnotetext{
1 The thickness of the enamel (and by subtracting this from the total calipered thickness, the thickness of the cast-iron base) may be determined conveniently without damaging the fixture, by using a thickness gage for nonmagnetic coatings on a magnetic base.
} 


\section{DEFINITIONS}

7. Inspection window.-A circular opening 3 inches in diameter cut from a small sheet of any flexible material, such as rubber or paper, for convenience in sliding over irregular surfaces to determine segregation. A segregation is a collection of blemishes within the inspection window greater than permitted by table 1 .

8. Flaws:

Cracked fixture.-A fixture with a rupture extending through both the casting and enamel.

Craze.-A crack in the enamel surface.

Lift.-An area of metal base from which the enamel has separated.

Pin hole.-A hole which extends through the enamel to the metal base.

9. Blemishes:

Dimple.-A slight depression in enamel surface.

Lump.-A raised portion of enamel surface.

Specks (Small).- Particles of foreign matter which produce a colored portion of the surface $1 / 100$ to $1 / 64$ inch in maximum dimension.

(Medium).- The same except over $1 / 64$ to $1 / 32$ inch in maximum dimension.

(Large).-The same except over $1 / 32$ to $1 / 16$ inch in maximum dimension.

Waviness.-The appearance of irregular surface in the glaze. Some waviness in an enamel surface is unavoidable and is not cause for rejection.

\section{INSPECTION RULES}

10. Examine the fixture with eyes of the observer about 2 feet from the surface observed. The light source shall be partially diffused daylight, supplemented, if necessary, with diffused artificial light, the total being of intensity approximating that usually available within a few feet of an outside window but not in direct sunlight. No actual count or measure of blemishes should be attempted except in case of doubt, since with practice dimensional limits and numbers can readily be gaged by the eye. No flaws shall be allowed. Some waviness in an enamel surface is unavoidable and is not cause for rejection. The number of other allowable blemishes shall not exceed those listed in table 1.

TABLE 1.-Allowable blemishes

\begin{tabular}{|c|c|c|c|}
\hline Description & Size or appearance & $\begin{array}{c}\text { Maximum } \\
\text { number } \\
\text { allowed per } \\
\text { window }\end{array}$ & $\begin{array}{l}\text { Maximum } \\
\text { number } \\
\text { allowed per } \\
\text { fixture }\end{array}$ \\
\hline Specks_-_--_---_-- & $\left\{\begin{array}{l}\text { Small } \\
\text { Medium }\end{array}\right.$ & $\stackrel{4}{2}$ & (a) \\
\hline Dimples...... & & 2 & 8 \\
\hline Lumps....... & 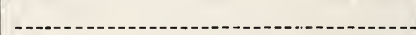 & 2 & 8 \\
\hline
\end{tabular}

- Not to be counted. 


\section{METHODS OF TEST}

11. Warpage.-The fixture is placed on a level table so as to ascertain the amount of deviation from the horizontal plane of the edges of the fixture. If a feeler gage of a thickness equal to the total allowable warpage will not slide under the fixture without forcing, the fixture satisfactorily comes within the warpage limitations. If it is observed that the fixture will rock on two opposite high corners, the horizontal plane shall be determined by placing one feeler gage of the total warpage allowed under one low corner and forcing the fixture down on this gage. If a second feeler gage of the same thickness will not slide under the fixture at any other point, the fixture is not warped out of the horizontal plane by more than the specified tolerance and satisfactorily comes within the warpage limitations.

12. Tests for acid-resisting enamel.

12a. Methods of test.-Acid-resisting enamel shall be subjected either to the lemon test or to the citric-acid test, as specified below, but in cases of dispute the citric-acid test shall be the umpire test. The test for subsurface acid resistance will be made at the option of the purchasing agency or the inspector.

12b. Lemon test.-A freshly cut half of a normally ripe lemon shall be applied to a cleaned area of the enameled ware, and after 24 hours at room temperature the lemon shall be removed and the surface washed with water and wiped dry. No effect on the enamel shall be visible upon careful inspection.

12c. Citric-acid test (umpire test).- $\mathrm{A}$ fresh test solution made of 1 part citric acid crystals to 10 parts water by weight shall be applied to the surface of the enamel for 15 minutes, at the end of which period, after washing and drying, no effect of the acid on the treated area shall be visible upon careful inspection. The ware and acid solution shall have been stored for not less than 3 hours immediately preceding the tests in an atmosphere at $80^{\circ} \mathrm{F}, \pm 10^{\circ} \mathrm{F}$, and the tests shall be made under these conditions of temperature. The test solution shall be applied to clean areas in pools consisting of several drops and covered with a watch glass to hold the solution in place.

12d. Test for subsurface acid resistance of enamel coatings on cast iron.-The test is ordinarily made on a flat or nearly flat specimen, 2 inches square, cut from the fixture.

(1) Grind off the enamel so as to expose a smooth oblique section of the coating and part of the metal base. Specimens cut from the article may be ground along a cut edge. The oblique section of enamel shall be $3 / 4$-inch, $\pm 1 / 8$-inch $(1.6$ to $2.2 \mathrm{~cm}$ ) wide. The abrasive used in grinding shall pass a No. 150 sieve and shall be moistened during grinding.

(2) Restore the gloss to the ground-enamel surface by refiring just sufficiently to obtain a fire polish. The polished surface shall permit ready cleaning with a dry cloth of marks made by a colored wax pencil.

(3) Apply the citric-acid test, as specified in paragraph $12 c$, to the full width of the fire-polished oblique section. The cut specimens may be immersed in the test solution. After application of the test solution for 15 minutes, the treated surface is washed and dried.

(4) The entire oblique section is rubbed with a colored wax pencil, and the deposit of colored wax rubbed with a dry cloth. If the wax cannot be readily and evenly removed from all portions of the treated 
area of enamel by rubbing, thus indicating that the enamel has been roughened by the test solution, the enamel will not be considered acid resisting throughout.

13. Trade-mark.-In order to fix the responsibility for quality, the cast-iron enameled ware shall bear the name or trade-mark duly applied for or registered under the laws of the United States, of the manufacturer of such cast-iron enameled ware. All acid-resisting enameled ware shall bear the manufacturer's mark permanently signifying acid-resisting material; these marks to be located if possible so as to be visible after the fixture is installed.

\section{LABELING}

14. In order that the purchaser may be assured that he is obtaining cast-iron enameled ware conforming to this standard, it is recommended that ware complying therewith shall bear a sticker or other label containing the following wording:

The manufacturer certifies that this piece of sanitary cast-iron enameled ware complies with all the requirements and tests of Commercial Standard CS77-40, issued by the National Bureau of Standards, United States Department of Commerce.

(This may be followed by the manufacturer's recommendations on handling, setting, and cleaning up.)

\section{EFFECTIVE DATE}

The standard is effective for new production from May 25, 1940.

\section{STANDING COMMITTEE}

The following comprises the membership of the standing committee which is to review, prior to circulation for acceptance, revisions proposed to keep the standard abreast of progress. Each association or organization nominated its own representative. Comment concerning the standard and suggestions for revision, may be addressed to any member of the committee or to the Division of Trade Standards, National Bureau of Standards, which acts as secretary for the committee.

Manufacturers:

J. J. Hall (chairman), American Radiator \& Standard Sanitary Corporation, Bessemer Bldg., Pittsburgh, Pa.

A. H. Cline, JR., United States Sanitary Manufacturing Co., Arrott Bldg., Pittsburgh, Pa.

C. W. Carbeau, Ellwood Co., Ellwood City, Pa.

Raymond E. Crane, The National Sanitary Co., Ford City, Pa.

Distributors:

The Central Supply Association, 228 N. LaSalle St., Chicago, Ill. Invited to name representative.

AlFred E. ElLIS, Sol Ellis \& Sons, Inc., 2118 South State St., Chicago, Ill. Representing National Supply Association of America, Inc.

G. A. BAEHR, Dept. 642, Sears, Roebuck \& Co., Chicago, Ill. Representing Mail Order Association of America.

Wholesale Distributors of Texas, 1134 Liberty Bank Bldg., Dallas, Tex. Invited to name representative. 
Consumers:

Jere L. Murphy, 340 E. 44th St., .New York, N. Y. Representing National Association of Master Plumbers.

Leon Chatelain, JR., Washington (D. C.) chapter, A. I. A., 544 Transportation Bldg., Washington, D. C. Representing the American Institute of Architects.

Robert K. Thulman, Technical Division, Federal Housing Administration, Washington, D. C.

Josephine L. Pierce, 1006 Cook Tower, Lima, Ohio. Representing General Federation of Women's Clubs.

\section{HISTORY OF PROJECT}

Following a series of industry meetings, the Sanitary Cast Iron Enameled Ware Association under date of March 28, 1939, requested the cooperation of the National Bureau of Standards in the establishment of a commercial standard for sanitary cast-iron enameled ware and submitted a proposed draft of the standard. This draft was circulated on April 12, 1939, to a number of interested national organizations for comment.

Following adjustment to suit the composite suggestions of interested national organizations of distributors, users, master plumbers, architects, and others, the revised draft was circulated to the trade for written acceptance under date of July 12, 1939. Upon receipt of written acceptances from a preponderant majority, an announcement was issued on September 11, 1939, that the standard would become effective for new production from October 10, 1939.

On March 30, 1940, a recommended revision submitted by the Sanitary Cast Iron Enameled Ware Association and endorsed by the standing committee was circulated to the trade. It added a requirement that acid-resisting enamel shall be acid resisting throughout its thickness; introduced some minor editorial changes in table 1 for consistency; and replaced the hydrochloric-acid test with the citric-acid umpire test. On recommendation of the standing committee in view of the minor character of the changes, the trade was notified that in the absence of objections the revision would be promulgated. Having received many additional acceptances and no objections, the establishment of the revision was announced on April 25, 1940, becoming effective for new production from May 25, 1940. 



\section{ACCEPTANCE OF COMMERCIAL STANDARD}

If acceptance has not previously been filed, this sheet properly filled in, signed, and returned will provide for the recording of your organization as an acceptor of this commercial standard.

Division of Trade Standards,

Date

National Bureau of Standards,

Washington, D. C.

Gentlemen:

Having considered the statements on the reverse side of this sheet, we accept the Commercial Standard CS77-40 as our standard of practice in the
Production ${ }^{1}$
Distribution ${ }^{1}$
Use ${ }^{1}$

of sanitary cast-iron enameled ware.

We will assist in securing its general recognition and use and will cooperate with the standing committee to effect revisions of the standard when necessary.

Signature of individual officer

(In ink)

(Kindly typewrite or print the following lines)

Name and title of above officer

Company

(Fill in exactly as it should be listed)

Street address

City and State

1 Please designate which group you represent by drawing lines through the other two. Please file separate acceptances for all subsidiary companies and affiliates which should be listed separately as acceptors.

In the case of related interests, trade papers, colleges, etc., desiring to record their general approval, the words "in principle" should be added after the signature. 


\section{TO THE ACCEPTOR}

The following statements answer the usual questions arising in connection with the acceptance and its significance:

1. Enforcement.-Commercial standards are commodity specifications voluntarily established by mutual consent of those concerned. They present a common basis of understanding between the producer, distributor, and consumer and should not be confused with any plan of governmental regulation or control. The United States Department of Commerce has no regulatory power in the enforcement of their provisions, but since they represent the will of the interested groups as a whole, their provisions through usage soon become established as trade customs and are made effective through incorporation into sales contracts by means of labels, invoices, and the like.

2. The acceptor's responsibility. - The purpose of commercial standards is to establish for specific commodities nationally recognized grades or consumer criteria and the benefits therefrom will be measurable in direct proportion to their general recognition and actual use. Instances will occur when it may be necessary to deviate from the standard and the signing of an acceptance does not preclude such departures; however, such signature indicates an intention to follow the commercial standard where practicable, in the production, distribution, or consumption of the article in question.

3. The Department's responsibility.-The major function performed by the Department of Commerce in the voluntary establishment of commercial standards on a Nation-wide basis is fourfold: First, to act as an unbiased coordinator to bring all interested parties together for the mutually satisfactory adjustment of trade standards; second, to supply such assistance and advice as past experience with similar programs may suggest; third, to canvass and record the extent of acceptance and adherence to the standard on the part of producers, distributors, and users; and fourth, after acceptance, to publish and promulgate the standard for the information and guidance of buyers and sellers of the commodity.

4. Announcement and promulgation.-When the standard has been endorsed by a satisfactory majority of production or consumption in the absence of active, valid opposition, the success of the project is announced. If, however, in the opinion of the standing committee or the Department of Commerce, the support of any standard is inadequate, the right is reserved to withhold promulgation and publication. 


\section{ACCEPTORS}

The organizations and individuals listed below have accepted this recorded standard of the industry as their standard of practice in the production, distribution, and use of sanitary cast-iron enameled ware. Such endorsement does not signify that they may not find it necessary to deviate from the standard, nor that producers so listed guarantee all of their products in this field to conform with the requirements of this standard. Therefore, specific evidence of conformity (quality certification) should be obtained where required.

\section{ASSOCIATIONS}

American Ceramic Society, Columbus, (Louisville Master Plumbers AssociaOhio.

American College of Surgeons, Chicago, Ill.

American Home Economics Assn., Washington, D. C.

American Institute of Architects, Washington Chapter, Washington, D. C.

American Sanatorium Association, New York, N. Y.

American Specification Institute, Chicago, Ill.

Arkansas City Master Plumbers' Association, Arkansas City, Kans.

Associated Clinics \& Hospitals, Inc., Minneapolis, Minn.

Association of American Railroads, Freight Container Bureau, New York, N. Y. (In principle.)

Binghamton, N. Y. Association of Master Plumbers, Binghamton, N. Y.

Bradenton Woman's Club, Bradenton, Fla.

Chattanooga Master Plumbers Association, Chattanooga, Tenn.

Cleveland, Master Plumbers' League of, Cleveland, Ohio.

Dallas, Associated Master Plumbers of, Dallas, Tex.

Denver Master Plumbers Association, Denver, Colo.

General Federation of Women's Clubs, Department of American Home, Lima, Ohio. (In principle.)

Industrial Safety Equipment Association, New York, N. Y.

Kalamazoo Association of Master Plumbers, Kalamazoo, Mich. tion, Louisville, $\mathrm{Ky}$.

Minnesota Master Plumbers Association, St. Paul, Minn.

National Association of Builders Exchanges, Washington, D. C.

National Association of Master Plumbers of the United States, Washington, D. C.

National Council of Women of the United States, Inc., New York, N. Y.

National Supply Association of America, Inc., Boston, Mass.

Saginaw Association of Master Plumbers, Saginaw, Mich.

Sanitary Cast Iron Enameled Ware Association, Pittsburgh, Pa.

Seattle, Associated Plumbing \& Heating Merchants of, Seattle, Wash. (In principle.)

South Dakota Association of Master Plumbers, Madison, S. Dak. (In principle.)

Structural Clay Products Institute, Inc., Washington, D. C. (In principle.)

Tennessee Association of Master Plumbers, Memphis, Tenn.

Texas, Wholesale Distributors Association of, Dallas, Tex.

Virginia Associated Plumbing \& Heating Contractors, Inc., Richmond, Va.

Vitreous China Plumbing Fixtures Association, Pittsburgh, Pa. (In principle.)

Wisconsin Master Plumbers Association, Milwaukee, Wis.

\section{FIRMS}

Adams, Franklin O., Tampa, Fla.

American Radiator \& Standard Sanitary

Ahlbach \& Mayer, San Francisco, Calif. Aird-Don Co., Troy, N. Y.

Alert Pipe \& Supply Co., Bay City, Mich.

Allen, Harris C., San Francisco, Calif.

Allen Co., Inc., Walter H., Dallas, Tex.

American Radiator \& Standard Sanitary Corporation, Pittsburgh, Pa.

Manufacturing Co., Minneapolis Branch, Minneapolis, Minn.

Andrews, Jones, Biscoe \& Whitmore, Boston, Mass.

Appleby Bros. \& Whittaker Co., Harrisburg, $\mathrm{Pa}$.

Arkansas, Baptist State Hospital of Little Rock, Ark. 
Auler, Jensen \& Brown, Oshkosh, Wis. Austin, O. M., Johnson City, N. Y.

Bailey-Farrell Co., Pittsburgh, Pa., and other cities.

Bailey \& Son, H. P., Plymouth, Mass.

Baker Manufacturing Co., Kansas City, Mo.

Baker Plumbing Co., Inc., Beaumont, Tex.

Baker Specialty \& Supply Co., Logansport. Ind.

Balch \& Lippert, Madison, Wis.

Bangs, E. Geoffrey, Piedmont, Calif.

Barney, W. Pope, Philadelphia, Pa.

Barr \& Creelman Mill \& Plumbing Supply Co., Rochester, N. Y.

Barrett Hardware Co., Joliet, IIl.

Barrett Supply Co., Augusta, Ga.

Bass Plumbing \& Heating Co., J. P., Fulton, Mo.

Baumer, Herbert, Columbus, Ohio.

Beacham \& LeGrand, Greenville, S. C.

Beardsley, Wallace P., Auburn, N. Y.

Beeson, Carroll O., Crawfordsville, Ind.

Beetcher \& Co., O. H., Racine, Wis.

Bell Hardware, Bolivar, N. Y.

Bellingham Plumbing Supply Co., Bellingham, Wash.

Bethlehem Plumbing Supply Co., Bethlehem, $\mathrm{Pa}$.

Bial, George F., Hasbrouck Heights, N. J.

Bickford, Robert Turner, Elmira, N. Y.

Biggs-Kurtz Hardware Co., The, Grand Junction, Colo.

Bilz \& Son, Wm. A., Spring Lake, Mich.

Bishop, Horatio W., Los Angeles, Calif.

Blackwell-Wielandy Co., St. Louis, Mo.

Blake \& Co., W. L., Portland, Maine.

Blake-Rounds Supply Co., Portland, Maine.

Blatter, R. H., Washington, D. C.

Blithe, Wesley Lesher, Philadelphia, Pa.

Bogner, Harry, Milwaukee, Wis.

Bohn \& Kern Supply Co., Zanesville, Ohio.

Bowman Supply \& Manufacturing Co., Inc., Pittsburgh, $\mathrm{Pa}$.

Bradley Co., J. R., Reno, Nev.

Bradley Supply Co., Chicago, Ill.

Brainerd, Harry B., New York, N. Y. (In principle.)

Braseth \& Houkom, Fargo, N. Dak.

Brazer, Clarence W., New York, N. Y.

Breedlove, C. L., Madison, S. Dak.

Brown, Floyd W., Minneapolis, Minn.

Brown, W. J., Cedar Rapids, Iowa

Brunswick-Balke-Collender Co., The, Chicago, Ill.

Brust, Peter, Milwaukee, Wis.

Buechner \& Orth, St. Paul, Minn. principle.)

Bullock Co., The H. D., Toledo, Ohio

Bumstead's Heating \& Plumbing, Colorado Springs, Colo.

Burnham Plumbing Co., San Francisco, Calif.

(In
Burtal Plumbing Supply, Inc., New York, N. Y.

Candela, Rosario, New York, N. Y.

Canfield Supply Co., Kingston, N. Y.

Cannon \& Mullen, Salt Lake City, Utah

Capital City Supply Co., Charleston, W. Va.

Capitol Supply Co., Lincoln, Nebr.

Carder, Macon, O., Amarillo, Tex.

Carstens Bros., Ackley, Iowa

Cayton, Herbert C., Honolulu, Hawaii.

Cedar Rapids Pump \& Supply Co., Cedar Rapids, Iowa

Central Plumbing Supply Co., The, Bridgeport, Conn.

Central Supply Co., Little Rock, Ark.

Ceramic Industry, Chicago, Ill. (In principle.)

Chandler Co., Cedar Rapids, Iowa

Channel Co., Long Beach, Calif.

Chapin, Rollin C., Minneapolis, Minn.

Chenoweth, James, Philippi, W. Va.

Child, Harry C., Sayre, Pa.

Children's Country Home, Westfield, N. J.

City Plumbing \& Heating Supply Co., Gainesville, Ga.

Clark, Carl W., Cortland, N. Y.

Clow \& Sons, James B., Chicago, Ill.

Coit, E., New York, N. Y.

Cole Supply Co., Ltd., Tuscaloosa, Ala.

Cole Supply Co., Geo. H., Troy, N. Y.

Columbia Pipe \& Supply Co., Chicago, Ill.

Community Plumbing Service, Venice, Calif.

Connecticut Plumbing Supply Co., Stamford, Conn.

Conrad \& Cummings, Binghamton, N. $Y$.

Conrow, H. S., Wichita, Kans.

Consoer, Townsend \& Quinlan, Chicago, Ill.

Consolidated Supply Co., Portland, Oreg.

Coolidge, Shepley, Bulfinch \& Abbott, Boston, Mass.

Cooper Supply Co., Tulsa, Okla.

Cooper Supply Co., Harry, Springfield, Mo.

Corbit's, Inc., Reading, $\mathrm{Pa}$.

County Seat Plumbing Supply Co., Inc., White Plains, N. Y.

Cram \& Ferguson, Boston, Mass.

Crane Co., Chicago, Ill.

Crane Enamelware Co., Chattanooga, Tenn.

Crowell \& Lancaster, Bangor, Maine

Cuthbert \& Cuthbert, Ann Arbor, Mich.

Dalton Supply Co., Clarks Summit, Pa.

Dalziel Plumbing Supplies, San Francisco, Calif.

Danser Manufacturing \& Supply Co., The, Weston, W. Va.

Dawson Plumbing Co., Austin, Tex.

De Jarnette, Charles W., Des Moines, Iowa 
Detroit, City of, Sewage Disposal|Grinnell Co., Inc., Minneapolis, Minn., Project, Detroit, Mich. (In principle.)

Deutz \& Bro., A., Laredo, Tex.

Dickinson Plumbing \& Heating Co., Villisca, Iowa.

Dietel, George J., Buffalo, N. Y.

District of Columbia, Government of, Washington, D. C.

Dodge \& Morrison, New York, N. Y.

Dubuque Supply Co., R. A., St. Louis, Mo.

Eastern Plumbing Supply Co., Inc., The, Hartford, Conn.

Egyptian Supply Co., Christopher, Ill., and Paducah, Ky.

Eldridge, Charles William, Oswego, N. Y.

Eljer Co., Ford City, Pa.

Ellis \& Sons, Inc., Sol, Chicago, Ill.

Ellsworth Pipe \& Supply Co., Milwaukee, Wis.

Ellwood Co., Ellwood City, Pa.

Emch Machinery \& Plumbing Supply Co., Nick, Toledo, Ohio.

Emery Industries, Inc., Cincinnati, Ohio.

English, Harold T., Hutchinson, Kans.

Fall River Steam \& Gas Pipe Co., Fall River, Mass.

Farr, Albert, \& J. Francis Ward, San Francisco, Calif.

Federal Pipe \& Supply Co., The, Toledo, Ohio.

Ferguson, James D., Saginaw, Mich.

Ferguson Supply Co., Grand Rapids, Mich.

Fix-Lippman Co., Chicago, Ill.

Flannagan, Eric G., Henderson, N. C.

Flatbush Plumbing Supply Co., Inc., Brooklyn, N. Y.

Foltz \& Son, Herbert, Indianapolis, Ind.

Fort Pitt Supply Co., Pittsburgh, Pa.

Frantz \& Spence, Saginaw, Mich.

Freeport Plumbing \& Heating Engineers, Freeport, N. Y.

Fresno Plumbing Supply Co., Fresno, Calif.

Frontier Water \& Steam Supply Co., Buffalo, N. Y.

Gaertner, Otto, New York, N. Y.

Gaines, Henry Irven, Asheville, N. C.

Galloup Pipe \& Supply Co., Battle Creek, Mich.

Gangwer, A. W., LaPorte, Ind.

Garber, Frederick W., Cincinnati, Ohio.

Gibb, Arthur N., Ithaca, N. Y.

Gibbons Supply Co., M. J., Dayton, Ohio.

Gilchrist, Edmund B., Philadelphia, Pa.

Globe Machinery \& Supply Co., Des Moines, Iowa.

Glustoff Co., D., Chicago, Ill.

Good Supply \& Equipment Co., Akron, Ohio.

Goodin Co., Minneapolis, Minn.

Grady Plumbing Co., Carbondale, 111.

and Providence, R. I.

Groeniger, Wm. C., Columbus, Ohio.

Hahn, Stanley W., Silver Spring, Md. (In principle.)

Hajoca Corporation, Philadelphia, Pa.

Hale Sheet Metal Works, John, Reedsville, Wis.

Hallberg \& Beersman, Chicago, Ill.

Hama Plumbing \& Heating Co., J. D., Chicago, Ill.

Hannaford \& Sons, Samuel, Cincinnati, Ohio.

Hansen Plumbing Co., Dallas, Tex.

Haralson \& Mott, Fort Smith, Ark.

Hardison Plumbing Co., Kiowa, Kans.

Harley \& Ellington, Detroit, Mich.

Harper \& West, Boston, Mass.

Hasness, Carlisle D., Harrisburg, Pa.

Hausman, N. W., Glen Cove, N. Y.

Helfensteller, Hirsch \& Watson, St. Louis, Mo.

Hellenthal Plumbing \& Heating Co., Seattle, Wash.

Helmle, Henry R., Springfield, Ill.

Hentz, Adler \& Shutze, Atlanta, Ga.

Herbst \& Kuenzli, Milwaukee, Wis.

Hering \& Sons, Philip, Philadelphia, Pa.

Hermitage Engineering Co., Nashville, Tenn.

Hess Co., Charles, New York, N. Y.

Higbro Engineering Co., Wellington, Kans.

Higgins, Charles H., New York, N. Y.

Hodgdon \& Son, Charles, Chicago, Ill.

Holsman \& Holsman, Chicago, Ill.

Home Plumbing \& Heating Co., Twin Falls, Idaho.

Honolulu Iron Works Co., Honolulu, T. H.

Hood River Plumbing Co., Hood River, Oreg.

Hopkins, Albert Hart, Buffalo, N. Y.

Hoppe, M. F., Washington, D. C. (In principle.)

Hospital Bureau of Standards \& Supplies, Inc., New York, N. Y.

Hubbard Co., The S. B., Jacksonville, Fla.

Hubert, Karl, Connersville, Ind.

Hughes Heating \& Plumbing Co., Minneapolis, Minn.

Hughes Supply Co., The, Mansfield, Ohio.

Humphreys Manufacturing Co., The, Mansfield, Ohio.

Hunting Co., The, Rochester, N. Y.

Hutchings, E. T., Louis ville, Ky.

Ideal Supply Co., Somerville, Mass.

Illinois, University of, Department of Architecture, Urbana, Ill. (In principle.)

Inland Supply Co., Danville, Ill.

Intermountain Consumers' Service, Inc., Denver, Colo.

Iowa Hospitals, State University of, Iowa City, Iowa. 
Iowa State College, Ames, Iowa. Ivey, Inc., Edwin J., Seattle, Wash. Jacobs Plumbing Supply Corporation, C. \& S., Brooklyn, N. Y.

Jahns Supply Co., Fort Worth, Tex.

Jamme, Bernard E., Summit, N. J.

Johns Hopkins Hospital, The, Baltimore, Md.

Johnson, Keplar B., Seattle, Wash. Johnson-Barker Co., Nashua, N. H.

Johnson Co., J. D., Pensacola, Fla.

Johnson Hardware Co. (formerly Johnson Supply Co.), Clarksburg, W. Va.

Johnson Plumbing Co., Texarkana, Ark.

Johnson, Wallwork \& Dukehart, Portland, Oreg.

Jones, Kay Co., Inc., Pendleton, Oreg. Jones \& Marsh, Portland, Oreg.

Kahn, Inc., Albert, Detroit, Mich.

Kalispell Mercantile Co., Kalispell, Mont.

Karcher, Walter T., \& Livingston Smith, Philadelphia, Pa.

Keich \& O'Brien, Warren, Ohio.

Keiser Van Leer Co., The, Bloomington, III.

Kelley, Frederic P., New York, N. Y.

Kiefaber Co., The W. H., Dayton, Ohio. Knapp Supply Co., The, Muncie, Ind.

Knighton \& Howell, Portland, Oreg.

Koepsell Co., J. J., Sheboygan, Wis.

Kohler Co., Kohler, Wis., and Omaha, Nebr.

Kohn, Robert D.-Chas. Butler, New York, N. Y.

Koller Bros. Co., The, Cleveland, Ohio. Kubias \& Co., F., Cedar Rapids, Iowa. Kyle, Herbert S., Charleston, W. Va.

La Crosse Plumbing Supply Co., La Crosse, Wis.

Laib Co., Louisville, Ky.

Lange Pipe \& Supply Co., Pasadena, Calif.

Lansing Supply Co., Lansing, Mich.

Larrick, Tom, Lawrence, Kans.

Latenser \& Sons, Inc., John, Omaha, Nebr.

Laughlin Co., The Thomas, Portland, Maine.

Law, Law \& Potter, Madison, Wis.

Lawrence, Holford \& Allyn, Portland, Oreg.

Lebanon Plumbing Supply Co., Lebanon, $\mathrm{Pa}$.

Lehigh Plumbing \& Heating Co., Allentown, $\mathrm{Pa}$.

Leighton Supply Co., Fort Dodge, Iowa.

Leon Heating \& Plumbing, J. H., Bloomfield, Iowa.

Levine, Samuel, New York, N. Y.

Levy, Will, St. Louis, Mo.

Liberty Plumbers Supply Co., Inc., Stapleton, Staten Island, N. Y.

Liggett Drug Co., Inc., New York, N. Y.

Loeb, Laurence N., White Plains, N. Y.

Long Beach, Better Business Bureau of, Long Beach, Calif.
Lorenz, Co., Klamath Falls, Oreg.

MacCornack, Walter R. \& Donald A., Cleveland, Ohio.

Malone Plumbing Supply Co., Pittsburgh, $\mathrm{Pa}$.

Manley \& Young, Inc., Knoxville, Tenn.

Mann \& Co., Hutchinson, Kans.

Marietta Hollow Ware \& Enameling Co., Marietta, Pa.

Martin \& Son, A. Oscar, Doylestown, $\mathrm{Pa}$.

Maryland Sanitary Manufacturing Corporation, The (Successors to A. Weiskittel \& Son Co.), Baltimore, Md. Mason \& Co., Geo. D., Detroit, Mich.

Massena \& DuPont, Wilmington, Del. Matt \& Nolting, Baltimore, Md.

Mauran, Russell, Crowell \& Mullgardt, St. Louis, Mo.

May Supply Co., Anderson, Ind.

McArdle \& Cooney, Inc., Philadelphia, $\mathrm{Pa}$.

MeDonald Manufacturing Co., A. Y., Hutchinson, Kans., and Omaha, Nebr.

McGowan Plumbing Co., Memphis, Tenn.

Mechanical Construction Corporation, Hibbing, Minn.

Merkel Brothers Co., The, Cincinnati, Ohio.

Meyer, F. \& J., New York, N. Y.

Michigan Supply Co., Lansing, Mich.

Mideke Supply Co., Oklahoma City, Okla.

Midland Plumbing Supply Co., Inc., East St. Louis, Ill.

Miller Supply Co., Chicago, Ill.

Miller \& Yeager, Terre Haute, Ind.

Milwaukee, City of, Public Works, Milwaukee, Wis.

Minneola Plumbing Supply Co., Inc., Minneola, N. Y.

Mission Pipe \& Supply Co., San Diego and Santa Ana, Calif.

Missoula Mercantile Co., Missoula, Mont.

Missouri Water \& Steam Supply Co., St. Joseph, Mo.

Molther, F. R., Ancon, Canal Zone.

Monroe Plumbing \& Heating Supply Co., Rochester, N. Y.

Montgomery \& Patteson, Charleston, W. Va.

Montgomery Ward \& Co., Chicago, Ill.

Moore, Alvin Roger, Atlanta, Ga.

Mooser, William, San Francisco, Calif.

Morrison Supply Co., Fort Worth, Tex.

Mott Co. of Pennsylvania, Philadelphia, $\mathrm{Pa}$.

Mueller, Fred G., \& Walter, R. Hair, Hamilton, Ohio.

Muhlenberg Brothers, Reading, Pa.

Mundie, Jensen, Bourke \& Havens, Chicago, Ill.

Murdock Manufacturing \& Supply Co., The, Cincinnati, Ohio.

Murphy, Inc., J. L., New York, N. Y. Murphy Supply Co., Green Bay, Wis. Musselman \& Schwarz, Lancaster, Pa. 
National Sanitary Co., The, Salem, Ohio.

Nelson Co., Detroit, Mich.

Nelson Co., N. O., St. Louis, Mo.

New England Plumbing Supply Springfield, Mass.

New Jersey Engineering \& Supply Co., Passaic, N. J.

New York State College of Ceramics, Alfred, N. Y. (In principle.)

Neyland Plumbing Supply Corporation, Passaic, N. J.

Northern Indiana Supply Co., Inc., Kokomo, Ind.

Norton, Paul W., Boston, Mass.

Officer, Gwynn, Berkeley, Calif.

Ohio Pipe \& Supply Co., Cleveland, Ohio.

Ohio State Supply Co., The, Youngstown, Ohio.

Oklahoma, University of, Norman, Okla.

Olsen \& Heffernan, San Francisco, Calif.

Orange Memorial Hospital, Orange, N.J.

O'Rourke Plumbing \& Heating Co., W. R., Walla Walla, Wash.

Ostergren, Robert C., Chicago, Ill.

Otto, H. W., Milwaukee, Wis.

P. \& H. Supply Co., The, Fort Wayne Ind.

Palmer Supply Co., Seattle, Wash.

Pancoast, Russell T., Miami Beach, Fla.

Paterson General Hospital, Paterson, N. J.

Peerless Colorado Co., Denver, Colo.

Peerless Missouri Co., St. Louis, Mo.

Peerless-Oklahoma Co., Oklahoma City, Okla.

Pehrson, G. A., Spokane, Wash.

Peninsular Supply Co., Fort Lauderdale, Fla., and other cities.

Pennsylvania Hospital, Philadelphia, $\mathrm{Pa}$.

Perth Amboy Hardware Co., Perth Amboy, N. J.

Petit \& Oman, Columbus, Ohio.

Plumbers \& Factory Supplies, Inc., Columbus, Ohio.

Plumbers' Supply Co., New Bedford, Mass.

Plumbers Supply Co., Tulsa, Okla.

Plumbers Supply Co. of St. Louis, St. Louis, Mo.

Plumbing \& Heating Selling Co., New Orleans, La.

Plumbing \& Heating Supply Co., Inc., Peoria, Ill.

Plumbing \& Heating Supply Co., Inc., The, Nashville, Tenn.

Praetorius Sanitary Plumbing, Wm., Grand Rapids, Mich.

Prescott Supply Co., Binghamton, N. Y.

Proudfoot-Rawson-Brooks \& Borg, Des Moines, Iowa.

Providence Plumbing Supply Co., Inc., Providence, R. I.
$\mathrm{Pa}$

Rather, Jr., J. T., Houston, Tex.

Rayl Co., The, Detroit, Mich.

Reeves Supply Co., Kansas City, Mo.

Reichle Supply Co., Saginaw, Mich.

Reid, William H., Billings, Mont.

Republic Pipe \& Supply Corporation, Boston, Mass.

Richmond Radiator Co., Inc., Uniontown, Pa.

Rindge \& Rindge, Grand Rapids, Mich.

Ritchie \& Associates, James H., Boston, Mass.

Roberts, Hamilton Co., Minneapolis, Minn.

Rochester, Board of Education of, Rochester, N. Y.

Rockford Plumbing Supply Co., Rockford, Ill.

Rodgers Supply Co., McKees Rocks, $\mathrm{Pa}$.

Rom Co., The Robert, Milwaukee, Wis.

Roosevelt Co., W. A., La Crosse, Wis.

Ross-Willoughby Co., The, Columbus and Springfield, Ohio.

Ruhe \& Lange, Allentown, $\mathrm{Pa}$.

Rundle Manufacturing Co., Milwaukee, Wis.

Sacramento, Better Business Bureau of, Sacramento, Calif. (In principle.)

St. John's Hospital, Brooklyn, N. Y.

St. Luke's Hospital, Bethlehem, Pa.

Salina Supply Co., The, Salina, Kans.

San Francisco, The Housing Authority of the City and County of, San Francisco, Calif.

Sanitary Plumbing Co., Redlands, Calif.

Sanitary Plumbing Supply Co., Jersey City, N. J.

Sanitary Supply Co., Avon, N. J.

Scamell, Ralph E., Topeka, Kans.

Schaefer Plumbing Supply Co., Buffalo, N. Y.

Schaeffler, Joseph C., New York, N. Y.

Schirmer, R. F., Woodhaven, N. Y.

Schoeppe, Edward, Philadelphia, Pa.

Scholl, Joseph, Philadelphia, Pa.

Schulte Plumbing \& Heating Co., Joplin, Mo.

Schulzke, William H., Moline, Ill.

Scranton Better Business Bureau, Scranton, $\mathrm{Pa}$. (In principle.)

Seashore Supply Co., Atlantic City, N. J.

Shanley, George H., Great Falls, Mont.

Shapiro Plumbing Supply Co., Inc., A., New York, N. Y.

Shaver, Chas. W., Salina, Kans.

Shaw, R. W., Enid, Okla.

Shire, Edward I., New York, N. Y.

Shivers Plumbing Supply Co., W. M., Houston, Tex.

Shutts \& Morrison, Erie, Pa. (In principle.)

Sidells, Arthur F., \& Ellis M. Keppal, Warren, Ohio.

Simpson, Inc., W. H., Olean, N. Y. 
Sirrine \& Co., J. E., Greenville, S. C. Sleeper, Harold R., New York, N. Y.

Small, Smith \& Reeb, Cleveland, Ohio.

Smolka Plumbing Supply Co., E., New York, N. Y.

Southern States Supply Co., Columbia, S. C.

Southland Supply Co., Inc., Dallas, Tex.

Spangler Plumbing \& Heating Co., Birmingham, Ala.

Speakman Co., Wilmington, Del.

Specification Record, Chicago, Ill.

Springfield Plumbing Supply Co., Springfield, Mass.

Standard Pipe \& Plumbing Supply Co., Kansas City, Mo.

Standard Plumbing \& Heating Co., Dumont, N. J.

Standard Plumbing Supply Co., New York, N. Y.

Standard Supply Co., The, Portsmouth, Ohio.

Star Plumbing \& Heating Supply Co., Yonkers, N. Y.

Staten Island Supply Co., Inc., West Brighton, S. I., N. Y.

Sterner Co., Edwin, Flint, Mich.

Stoetzel, Ralph E., Chicago, Ill.

Stopper, Eugene A., Philadelphia, Pa.

Stratton Supply Co., Inc., Petersburg, Va.

Stravs, Carl B., Minneapolis, Minn.

Sturgis Supply Co., Sturgis, Mich.

Suiter Plumbing \& Heating Co., H. A., Oskaloosa, Iowa.

Sullivan County Plumbing \& Heating Supply Co., Inc., Liberty, N. Y.

Summers Hardware \& Supply Co., Johnson City, Tenn.

Swank Hardware Co., The, Johnstown, $\mathrm{Pa}$.

Sweet's Catalogue Service, New York, N. Y. (In principle.)

Tallman Co., St. Louis, Mo.

Tavlor, Ed B., Port Angeles, Wash.

Taylor, Edward Gray, Los Angeles, Calif.

Taylor, Ellery K., Philadelphia, Pa.

Taylor, Ellis Wing, Los Angeles, Calif.

Taylor, Henry L., St. Petersburg, Fla.

Tenth Avenue Plumbing Supply Co., Inc., New York, N. Y.

Texas Technological College, Department of Architecture \& Allied Arts, Lubbock, Tex. (In principle.)

Thomas, J. L., Traer, Iowa.

Thornley Supply Co., The, Pawtucket, R. I.

Tilden \& Pepper, Philadelphia, Pa.

Tomlinson Co., Inc., Richmond, Va.

Townsend \& Gehron, Martinsville, Ohio

Toye Supply Co., E. W., Winona, Minn.

Trenton Plumbing Supply Co., Trenton, N. J.
Trimble \& Lutz Supply Co., Wheeling, W. Va.

Trumbull Plumbing Supply Co., Warren, Ohio, and Youngstown, Ohio

Tumalty Plumbing Co., Jos. F., St. Louis, Mo.

Tyson Bros., Mesa, Ariz.

United Pipe \& Supply Co., Inc., Norristown, Pa.

United States Sanitary Manufacturing Co., Pittsburgh, Pa.

Universal Sanitary Manufacturing Co., New Castle, Pa. (In principle.)

Upman \& Adams, Washington, D. C. U. S. Supply Co., Wichita, Kans.

Valley Plumbing \& Heating Supply Co., Menasha, Wis.

Van Camp Hardware \& Iron Co., Indianapolis, Ind.

Van Denberg Supply Co., Rockford, Ill.

Virginia Polytechnic Institute, Blacksburg, Va. (In principle.)

Vogel, Joshua H., Seattle, Wash.

Vogel, Willis A., Toledo, Ohio

Vogel \& Sons Co., P. A., Louisville, Ky.

Voorhees, Walker, Foley \& Smith, New York, N. Y.

Vorse, Norman T., Houston, Tex.

Wagner \& Sons, Michael, Chicago, Ill.

Ware \& McClenahan, Salt Lake City, Utah

Warren, Balderston Co., Trenton, N. J.

Warren Plumbers' Supply Co., Inc., Jersey City, N. J.

Washington-Eljer Co., Los Angeles, Calif.

Webb Manufacturing Co., F. W., Boston, Mass.

Weber \& Co., Inc., C. L., Philadelphia, $\mathrm{Pa}$.

Weil-McLain Co., Chicago, Ill.

Welch, Carroll E., Huntington, N. Y.

Westchester Square Plumbing Supply Co., Inc., New York, N. Y.

Western Maryland Supply Corporation, Hagerstown, Md.

Western Metal Supply Co., San Diego, Calif.

Westwater Supply Co., The, Columbus, Ohio

Whitney \& Ford Co., Chicago, Ill.

Whitsitt, H. W., San Francisco, Calif. Wilkins Pipe \& Supply, Peoria, Ill.

Willatsen, Andrew, Seattle, Wash.

Williams, Coile \& Pipino, Newport News, Va.

Willson, Fred F., Bozeman, Mont.

Winterbottom Supply Co., Waterloo, Iowa.

Wischmeyer, Wm. F., St. Louis, Mo. Woltersdorf, Arthur, Chicago, Ill.

Wood \& Son, Associates, Edward J., Clarksburg, W. Va.

Woolcock Plumbing \& Heating Co., Niagara Falls, N. Y. 
Worthington Co., George, Cleveland, /Young Supply Co., W. B., Kansas City, Ohio

Wright, Frank H., Detroit, Mich. (In principle.)

Yelton-Weaver Supply Co., Springfield, Ill.

Young, A. M., Seattle, Wash. Mo.

Zimmer Plumbing Co., H. E., Canton, Ohio

Zimmerman, A. C., Los Angeles, Calif.

Zimmerman, Inc., Joseph, Staten Island, N. Y.

Zoller \& Muller, New York, N. Y.

U. S. GOVERNMENT

Federal Works Agency, Public Buildings $\mid$ National Youth Administration for Administration, Washington, D. C. Ohio, Columbus, Ohio

Federal Works A gency, United Veterans' Administration, Washington, States Housing Authority, Washington, D. C.

D. C.

War Department, Washington, D. C. 


\title{
COMMERCIAL STANDARDS
}

CS No.

$$
\text { Item }
$$

0-40. Commercial standards and their value to business (third edition).

1-32. Clinical thermometers (second edition).

2-30. Mopsticks.

3-38. Stoddard solvent (second edition).

4-29. Staple porcelain (all-clay) plumbing fixtures.

5-40. Pipe nipples; brass, copper, steel, and wrought iron.

6-31. Wrought-iron pipe nipples (second edition). Superseded by CS5-40.

7-29. Standard weight malleable iron or steel screwed unions.

8-33. Gage blanks (second edition).

9-33. Builders' template hardware (second edition).

10-29. Brass pipe nipples. Superseded by CS5-40.

11-29. Regain of mercerized cotton yarns.

12-40. Fuel oils (fifth edition).

13-39. Dress patterns (second edition).

14-39. Boys' button-on waists, shirts, junior and polo shirts (made from woven fabrics) (second edition).

15-29. Men's pajamas.

16-29. Wallpaper.

17-32. Diamond core drill fittings (second edition).

18-29. Hickory golf shafts.

19-32. Foundry patterns of wood (second edition).

20-36. Staple vitreous china plumbing fixtures (second edition).

21-39. Interchangeable ground-glass joints, stopcocks, and stoppers (fourth edition)

22-30. Builders' hardware (nontemplate).

23-30. Feldspar.

24-30. Standard screw threads.

25-30. Special screw threads.

26-30. Aromatic red cedar closet lining.

27-36. Mirrors (second edition).

28-32. Cotton fabric tents, tarpaulins, and covers.

29-31. Staple seats for water-closet bowls.

30-31. Colors for sanitary ware.

31-38. Wood shingles (fourth edition).

$32-31$. Cotton cloth for rubber and pyroxylin coating.

33-32. Knit underwear (exclusive of rayon).

34-31. Bag, case, and strap leather.

35-31. Plywood (hardwood and eastern red cedar)

36-33. Fourdrinier wire cloth (second edition).

37-31. Steel bone plates and screws.

38-32. Hospital rubber sheeting.

39-37. Wool and part wool blankets (second edition).

40-32. Surgeons' rubber gloves.

41-32. Surgeons' latex gloves.

42-35. Fiber insulating board (second edition).

\author{
CS No. \\ Item
}

43-32. Grading of sulphonated oils.

44-32. Apple wraps.

45-38. Douglas fir plywood (domestic grades) (third edition).

46-36. Hosiery lengths and sizes (second edition)

47-34. Marking of gold-filled and rolled-gold-plate articles other than watch cases.

48-34. Domestic burners for Pennsylvania anthracite (underfeed type)

49-34. Chip board, laminated chip board, and miscellaneous boards for bookbinding purposes.

50-34. Binders' board for bookbinding and other purposes.

51-35. Marking articles made of silver in combination with gold.

52-35. Mohair pile fabrics (100-percent mohair plain velvet, 100 -percent mohair plain frieze, and 50 -percent mohair plain frieze).

35. Colors and finishes for cast stone.

54-35. Mattresses for hospitals.

55-35. Mattresses for institutions.

56-36. Oak flooring.

57-36. Book cloths, buckrams, and impregnated fabrics for bookbinding purposes except library bindings.

58-36. Woven elastic fabrics for use in overalls (overall elastic webbing).

59-39. Woven dress fabrics-testing and reporting (second edition).

60-36. Hardwood dimension lumber

61-37. Wood-slat venetian blinds.

62-38. Colors for kitchen accessories.

63-38. Colors for bathroom accessories.

64-37. Walnut veneers.

65-38. Wool and part-wool fabrics.

66-38. Marking of articles made wholly or in part of platinum.

67-38. Marking articles made of karat gold.

68-38. Liquid hypochlorite disinfectant, deodorant, and germicide.

69-38. Pine-oil disinfectant.

70-38. Coal-tar disinfectant (emulsifying type).

71-38. Cresylic disinfectants.

72-38. Household insecticide (liquid spray type).

73-38. Old growth Douglas fir standard stock doors.

74-39. Solid hardwood wall paneling.

75-39. Automatic mechanical draft oil burners.

76-39. Hardwood interior trim and molding.

77-40. Sanitary cast iron enameled ware.

78-39. Ground-and-polished lenses for sun glasses.

79-39. Blown, drawn, and dropped lenses for sun glasses.

NoticE.-Those interested in commercial standards with a view toward accepting them as a basis of every-day practice may secure copies of the above standards, while the supply lasts, by addressing the Division of Trade Standards, National Bureau of Standards, Washington, D. C. 

